\title{
Assessing quality of life in patients with mastocytosis: development of the disease-specific questionnaire
}

\author{
Natalia Spolak-Bobryk ${ }^{1}$, Marek Niedoszytko', Ewa Jassem ${ }^{1}$, Marta Chełmińska $^{1}$, Magdalena Lange ${ }^{2}$, \\ Mikołaj Majkowicz ${ }^{3}$, Bogusław Nedoszytko², Judyta Borchet ${ }^{4}$
}

${ }^{1}$ Department of Allergology, Medical University of Gdansk, Gdansk, Poland

${ }^{2}$ Department of Dermatology, Venereology and Allergology, Medical University of Gdansk, Gdansk, Poland

${ }^{3}$ Faculty of Health Sciences, Pomeranian University, Slupsk Poland

${ }^{4}$ Institute of Psychology, University of Gdansk, Gdansk, Poland

Adv Dermatol Allergol 2021; XXXVIII (6): 1044-1051

DOI: https://doi.org/10.5114/ada.2021.108435

\begin{abstract}
Introduction: Appropriate and targeted psychological care, as well as psychoeducation covering the disease causes, symptoms, and their management are crucial elements of the therapeutic process in patients with mastocytosis. This care is based on the identification of problematic areas that are of the greatest importance for patients. The quality of life questionnaires available in Poland are designed for the general population; therefore, they do not encompass the specificity of difficulties experienced by people suffering from mastocytosis.

Aim: To develop a questionnaire measuring the quality of life in patients with mastocytosis, and including the issues and symptoms typical for this group.

Material and methods: The study involved 85 patients ( 57 women and 28 men) suffering from mastocytosis.

Results: The analyses revealed that the Quality of Life in Mastocytosis Scale (QLMS) is a reliable and valid tool for measuring the quality of life, and it takes into account the specific difficulties experienced by patients with mastocytosis. Apart from the measurement of the global quality of life, QLMS offers a deeper assessment of the quality of patient's lives, including the difficulties in professional life, everyday life, leisure time, or those associated with protective behaviours.

Conclusions: The presented questionnaire completes a gap in quality-of-life studies by allowing to plan psychoeducation and offering a tool for a precise diagnosis of the quality of life in patients with mastocytosis.
\end{abstract}

Key words: mastocytosis, quality of life, questionnaire.

\section{Introduction}

Mastocytosis is a rare disease caused by proliferation and accumulation of mastocytes (mast cells) in one or multiple organs. The symptoms of the disease are caused by skin lesions, anaphylaxis, osteoporosis and impairment of the function of infiltrated organs in aggressive forms of the disease [1, 2].

The most frequently infiltrated organs include stomach, skin, bone marrow, lymph nodes, intestines, spleen, and liver [3-5]. The condition occurs in both men and women, in all ethnic groups [6]. Its prevalence is estimated at under $0.01 \%$ of the general population [7], and its incidence is 3 persons per 1,000,000 annually [8]. Two periods of peak incidence are observed: the first one is infancy when the disease manifests as urticaria pigmentosa ( $66 \%$ of patients) [9], and the second one is the age of 30-40 years old.

Mastocytosis imposes a physical and mental burden on the organism, and its symptoms include somatic and psychological ones. The most frequent symptoms reported by patients include reduced body weight, abdominal pain, diarrhoea, gastric ulcer, and intestinal ulceration with haemorrhage. The neurological symptoms associated with infiltration of the brain structures include headache, described by patients as "dull" (primarily in the frontal region), vascular pains resembling migraine, and histaminergic pain, associated with lacrimation, pruritus and nasal discharge, as well as allergic disorders (presenting mainly as rash) $[2,10]$. Previous scientific

Address for correspondence: Natalia Spolak-Bobryk, Department of Allergology, Medial University of Gdańsk, 17 Mariana Smoluchowskiego St, 80-214 Gdansk, Poland, e-mail: natalia.spolak@gumed.edu.pl Received: 29.09.2019, accepted: 29.07.2020. 
publications report the following psychological symptoms observed in patients: permanent fatigue $(76 \%$ of cases), confusion and cognitive disorders (67\%), sleep disorders (60\%), depression (49\%) [7], reduced motivation, irritability, nervousness, negative emotions, and reduced resistance to stress [11]. Mood disorders are also characteristic of the disease: a significant reduction (95\%), decreased sexual performance, temporary fits of anger, anxiety, reduced quality of life and satisfaction with life, and apathy. Skin lesions and their treatment often considerably contribute to the psychological burden associated with the disease. The above psychological problem frequently affect patients' lives. They may result in an inability to perform professional work or everyday activities (97\%), irritability (83\%), sense of guilt (61\%), erectile dysfunction (56\%), insomnia (39\%) and suicidal thoughts (30\%). In addition, $22 \%$ of patients suffer from somatic symptoms, $21 \%$ experience increased nervous tension, and $16 \%$ are diagnosed with hypochondria [12].

The estimated mean time between the disease onset and diagnosis followed by the initiation of treatment is 7 years [10]. Educational conversations between physicians and patients are of great importance as they provide patients with a fundamental understanding of the disease and important related issues, such as factors that might trigger an anaphylactic shock [6]. Education and reliable information regarding the course of mastocytosis and available treatment options play an important role in therapy and reduce the level of stress and anxiety in patients. The effect of the disease on a patient's life is difficult to determine, due to the complexity, changeability, and varied course of mastocytosis, as well as the presence of comorbidities. It depends primarily on the subjective evaluation of symptoms by the patient, and not on their subjective intensity [7, 12]. From the psychological point of view, it is particularly important to base the therapy and care on accurate identification and naming of the problem areas that are of greatest significance to the patient. In addition, determination of the effect of areas on a patient's life is necessary [2]. It requires creating a psychological questionnaire that covers the domains specific to mastocytosis, with special focus on the measurement of life quality and satisfaction. This evaluation directly affects the patient's health condition and mental status, and it is closely associated with the sense of coherence or lack thereof in the way patients perceive their position in life. It is also a crucial element of the treatment $[13,14]$.

The relevant literature offers many questionnaires assessing the quality of life, adapted to the Polish cultural context (e.g. Polish version of the Satisfaction With Life Scale (SWLS) [15] or the World Health Organization Quality of Life-BREF (WHOQOL-BREF)) [16]. However, they are designed for the general population; therefore, they do not encompass the specificity of difficulties experienced by people suffering from mastocytosis.

\section{Aim}

The aim of the presented study was to develop a QOL questionnaire for patients with mastocytosis, including the issues and symptoms typical for this group of patients. This questionnaire fills the gap in the QOL studies and will enable a precise future diagnosis of the quality of life in patients with mastocytosis, as well as comprehensive planning of psychoeducation.

\section{Material and methods}

The study involved 85 patients ( 57 women and 28 men) aged $46.22 \pm 13.10\left(M_{\text {men }}=40.55, M_{\text {women }}=44.2\right.$; $Z=-0.64, p<0.05)$ with mastocytosis treated at the Department of Allergology, University Clinical Centre in Gdansk (Poland). The cutaneous mastocytosis (CM) was diagnosed in 19 (22.4\%) patients, indolent systemic mastocytosis (ISM) in 66 (77.6\%) patients. The majority of participants had higher education (55.3\%). The rest of the group had secondary education (27.1\%), vocational $(12.9 \%)$ or primary education (4.7\%). The participant's relationship status was as follows: married (75.3\%), single (18.9\%), widowed (3.5\%), and divorced (2.4\%). A vast majority of the participants were employed $(71.8 \%)$. More people were retired or receiving a pension (18.9\%) than unemployed, who comprised $9.4 \%$ of the studied population.

The study was approved by the Independent Bioethical Committee for Scientific Research at the Medical University of Gdansk (approval no. NKBBN/550/2015). Participation in the study was anonymous and voluntary. All patients signed informed consent to participate in the project. The testing time was approximately $30-40 \mathrm{~min}$. The study procedures started in 2015 and were completed in 2019.

The following questionnaires were used: HADS-M, EORTC QLQ-C30, STAI, Cantril Ladder, SWLS, and an initial version of Quality of Life in Mastocytosis Scale (QLMS).

HADS-M, formerly known as HADS Hospital Anxiety and Depression Scale by Zigmond and Snaith. The Polish version was modified by Majkowicz, de Walden-Gałuszko and Chojnacka-Szawłowska [17]. HADS-M comprises three subscales: depression (HADS-D), anxiety (HADS-A), and aggression. It helps to assess the presence of these symptoms in patients hospitalized due to somatic causes. The scale includes 16 statements, assessed on a 4-point scale: definitely yes, rather yes, rather no, definitely no. The possible scores range from 0 to 21 points. Scores from 0 to 7 are considered normal, from 8 to 10 are borderline, those above 11 signify a high level of anxiety and/or depression in the setting of a hospital medical outpatient clinic [18].

The EORTC QLQ-C30 questionnaire (version 3.0) was created by the European Organization for Research Treatment of Cancer (EORTC) [19]. This scale measures the global quality of a patient's life using five functional subscales: physical (PF; 1-5), role (RF; 6,7), emotional (EF; 
21-24), social (SF; 26,27) and cognitive functioning (CF; 20,25). Three subscales describe symptoms: fatigue (FA; 10,12,18), nausea and vomiting (NV; 14,15), and pain (PA; $9,19)$. There is also a global health status/QOL subscale (QL; 29,30). In addition, six single questions assess disease symptoms such as loss of appetite (AP; 13), dyspnoea (DY; 8), sleeplessness (SL; 11), constipation (CO; 16), diarrhoea (DI; 17) and financial difficulties due to the disease (FI; 28). The questionnaire was adapted by EORTC in over 80 language versions, including Polish.

The State-Trait Anxiety Inventory (STAI) developed by Spielberger CD, Gorsuch RL, Lushene RE, and adapted to the Polish version by Spielberger CD, Strelau J, Tysarczyk M, and Wrześniewski $\mathrm{K}$, is a tool for analysing anxiety in two ways. It can be defined as a transient, situationally determined state of a person (anxiety as the state), or perceived as a relatively permanent personality trait characterizing the individual in general (anxiety as the trait). STAl is composed of two subscales: $X-1$ measures anxiety - state, and X-2 measures anxiety - trait. The subscales are placed on both sides of one test sheet, and each of them comprises 20 questions. The possible scores range from 0 to 100 points. A result under 39 corresponds to low anxiety, 40-60 corresponds to the normal level of anxiety, and 61 or higher signifies pathological anxiety $[20,21]$.

Cantril Ladder (Cantril, 1965) is a visual test assessing mental well-being. It is presented in the form of a ladder, whose steps are marked with consecutive numbers from 0 to 10 . The text on the side of the ladder clarifies that the top number 10 means the best possible life, and the bottom number 0 - the worst life. The respondent evaluates his or her life at the moment and puts an $X$ on the right step of the ladder [22]. Level 6 or higher is considered to signify a considerable satisfaction with life, whereas lower scores identify people unsatisfied with their lives.

SWLS (Satisfaction with Life Scale) is used to analyse the subjective satisfaction with the quality of one's life. The SWLS test comprises five statements. Each question can be answered with the use of a 7-point scale [23, 24].

In its initial version, QLMS (Quality of Life in Mastocytosis Scale) comprised 112 questions, of which 34 referred to somatic symptoms, 15 were related to psychological symptoms, and 69 pertained to the limitations experienced by patients with mastocytosis in various areas of life. The questions about limitations in various areas of life were inspired by: (1) our own observations made in the clinical setting, (2) problems discussed by Russel, based on the questionnaire conducted in patients treated for mastocytosis in the USA, members of the Mastocytosis Society (2018) [25], as well as (3) by VQLQPL (Vespid Allergy Quality of Life Questionnaire), which is a Polish version of VQLQ-EN (The Vespid Allergy Quality of Life Questionnaire) [26-28]. The responses assessed the intensity of limitations on an increasing scale, with scores from 0 (no limitations in a given area) to 5 points (the limitation prevents normal functioning).

\section{Statistical analysis}

The statistical analysis was performed using Statistica 13.0 (StatSoft Inc.) and IBM SPSS Statistics 23. Data on continuous variables (e.g. age, HADS, STAI) were presented as medians and standard deviations (SD) (Supplementary material, Attachment 1). The gender differences in questionaries' scores were analysed using the U Mann Whitney test and are presented in Attachment 2, alongside with medians are quartiles. Values of $p<0.05$ were considered statistically significant.

Preliminary analyses were aimed to examine which of 112 questions are the best to differentiate patients in terms of their depression and anxiety level. The descriptive statistics for the variables used in the preliminary analyses are presented in a Supplementary Table S1. Due to the fact that women outweigh men in the sample, to test gender differences in study variables, non-parametric analyses were performed. There were no significant differences between men and women in almost all psychological variables ( $p>0.5$ ) (Supplementary Table S2). The only significant difference was in physical functioning (PF) which was significantly higher in men. Therefore, in further analyses, women and men were included in one sample.

There were 45 questions that emerged from the preliminary analyses and were included in further analyses. The next step of analyses was performing exploratory factor analysis (EFA). The study employed principal component analysis followed by oblimin rotation. The number of dimensions presented in the factor analysis was based on the landfill plot. Items with factor loadings equal to 0.3 or higher were included in particular factors [29]. Finally, investigation of the internal consistency of the QLMS sub-scales was calculated with Cronbach's $\alpha$.

\section{Results}

The study involved 85 patients (57 women and 28 men) suffering from mastocytosis, treated at the Department of Allergology, University Clinical Centre in Gdansk (Poland). There is no gender predilection in mastocytosis [6], women were a little overrepresented in our sample. All the participants were invited to join the study while visiting the clinic by the clinic's psychologists. None of them denied the request. The data regarding the sex ratio, age, and diagnosis of the subjects are presented in the tables below (Tables 1 and 2).

The initial factor analysis revealed 11 factors, which explained $75 \%$ of the total variance of 45 preliminary questions were selected. The principal component analysis supported the use of factor analysis (KMO > 0.5). The test items are correlated, as demonstrated by the statistically significant result of Bartlett's sphericity test (Table 3). Eleven 
Table 1. Patient characteristics

\begin{tabular}{lcc}
\hline Gender & Men 28 (33\%) & Women 57 (67\%) \\
\hline Age & $M=45.32 ;$ SD $=10.80$ & M = 46.67; SD = 14.16 \\
\hline Diagnosis of mastocytosis & Cutaneous mastocytosis (CM) 19 (22.4\%) & Systemic mastocytosis (SM) \\
& & 66 (77.6\%) \\
\hline Diagnosis of mastocytosis by gender & Women 14 (24.6\%) & Women 43 (75.4\%) \\
& Men 5 (17.9\%) & Men 23 (82.1\%) \\
\hline
\end{tabular}

Table 2. Psychological diagnosis - descriptive statistics $(n=85)$

\begin{tabular}{lcccc}
\hline Variable & Min. & Max. & Mean & SD \\
\hline Cantril - today & 7.39 & 1.59 & 3.0 & 10.0 \\
\hline Cantril - next 4 weeks & 7.80 & 1.51 & 4.0 & 10.0 \\
\hline SWLS & 24.74 & 4.95 & 13.0 & 35.0 \\
\hline HADS-M ANXIETY & 0.0 & 17.0 & 5.47 & 4.06 \\
\hline HADS-M DEPRESSION & 0.0 & 9.0 & 2.99 & 2.94 \\
\hline HADS-M RAGE & 0 & 6 & 2.59 & 1.58 \\
\hline STAI - state & 36.36 & 12.12 & 20.0 & 63.0 \\
\hline STAI - trait & 39.19 & 10.05 & 20.0 & 62.0 \\
\hline GQL - Global health status & 25 & 100 & 73.63 & 17.15 \\
\hline NV - Nausea and vomiting & 0 & 66.67 & 5.49 & 12.17 \\
\hline P - Pain & 0 & 100 & 25.49 & 23.37 \\
\hline D - Dyspnoea & 0 & 66.67 & 9.02 & 18.10 \\
\hline S - Insomnia & 0 & 100 & 30.59 & 30.52 \\
\hline A - Appetite loss & 0 & 66.67 & 10.98 & 18.10 \\
\hline C - Constipation & 0 & 66.67 & 9.02 & 18.82 \\
\hline DIA - Diarrhoea & 0 & 100 & 27.06 & 31.49 \\
\hline FIN - Financial difficulties & 0 & 100 & 6.27 & 18.18 \\
\hline PF1 - Physical functioning & 26.67 & 100 & 84.94 & 15.12 \\
\hline RF1 - Role functioning & 0 & 100 & 81.57 & 23.99 \\
\hline CF1 - Cognitive functioning & 0 & 100 & 81.18 & 20.22 \\
\hline EF1 - Emotional functioning & 0 & 100 & 77.16 & 21.33 \\
\hline SF1 - Social functioning & 0 & 100 & 88.04 & 20.02 \\
\hline & & & \\
\hline
\end{tabular}

Table 3. Kaiser-Meyer-Olkin test and Bartlett's test

\begin{tabular}{lccc}
\hline Variable & $\begin{array}{c}\text { 11-factor } \\
\text { solution }\end{array}$ & $\begin{array}{c}\text { 4-factor } \\
\text { solution }\end{array}$ \\
\hline KMO sampling adequacy measure & 0.738 & 0.844 \\
\hline $\begin{array}{l}\text { Bartlett's sphericity } \\
\text { test }\end{array}$ & Estimated $\chi^{2}$ & 3118.007 & 1494.27 \\
\cline { 2 - 4 } & Df & 990 & 276 \\
\cline { 2 - 3 } & Significance & 0.0001 & 0.000 \\
\hline
\end{tabular}

subscales were selected in the initial factor analysis. The total variance explained by an 11 -factor solution was $75.56 \%$. The initial exploratory factor analysis allocated 45 questions to 11 subscales (Supplementary Table S3).
Table 4. Structure and reliability of the Quality of Life in Mastocytosis Scale

\begin{tabular}{|c|c|c|}
\hline Does your disease make you & Subscale & $\begin{array}{c}\text { Reliability } \\
\text { (Cronbach's } \alpha)\end{array}$ \\
\hline 43. Feel anxious during a walk? & \multirow{9}{*}{$\begin{array}{l}\text { Leisure } \\
\text { time }\end{array}$} & \multirow[t]{9}{*}{0.918} \\
\hline 42. Go on walks less often? & & \\
\hline 20. Visit your family less often? & & \\
\hline 51. Feel anxious while on holidays? & & \\
\hline 47. Go on holidays less often? & & \\
\hline $\begin{array}{l}\text { 53. Use preventive measures on } \\
\text { holidays? }\end{array}$ & & \\
\hline 32. Work in the garden less often? & & \\
\hline 52. More careful on holidays? & & \\
\hline $\begin{array}{l}\text { 50. Adjust the way you spend your } \\
\text { holidays? }\end{array}$ & & \\
\hline $\begin{array}{l}\text { 30. Close doors and windows more } \\
\text { often? }\end{array}$ & \multirow[t]{6}{*}{$\begin{array}{l}\text { Protective } \\
\text { behaviours }\end{array}$} & \multirow[t]{6}{*}{0.840} \\
\hline 18. Use more insect repellents? & & \\
\hline $\begin{array}{l}\text { 29. Install an anti-insect net in } \\
\text { windows or doors? }\end{array}$ & & \\
\hline $\begin{array}{l}\text { 38. Close bottles. cover cups with } \\
\text { drinks? }\end{array}$ & & \\
\hline 34. Eat outside less often? & & \\
\hline $\begin{array}{l}\text { 31. Feel limited while working in the } \\
\text { garden? }\end{array}$ & & \\
\hline 1. Work less outside/in open air? & \multirow{4}{*}{$\begin{array}{c}\text { Professional } \\
\quad \text { life }\end{array}$} & \multirow[t]{4}{*}{0.812} \\
\hline 2. Work more indoors? & & \\
\hline $\begin{array}{l}\text { 4. Feel less comfortable at your } \\
\text { workplace? }\end{array}$ & & \\
\hline $\begin{array}{l}\text { 39. Limit the number of things to } \\
\text { do? }\end{array}$ & & \\
\hline $\begin{array}{l}\text { 25. Experience discomfort while } \\
\text { doing house chores? }\end{array}$ & \multirow[t]{5}{*}{$\begin{array}{l}\text { Life } \\
\text { limitations }\end{array}$} & \multirow[t]{5}{*}{0.834} \\
\hline 26. Grow fewer flowers at home? & & \\
\hline 36. Uncomfortable during meals? & & \\
\hline $\begin{array}{l}\text { 40. Uncomfortable while doing } \\
\text { certain chores? }\end{array}$ & & \\
\hline $\begin{array}{l}\text { 68. Limit a spontaneous } \\
\text { performance of certain } \\
\text { activities? }\end{array}$ & & \\
\hline
\end{tabular}


Table 5. QLMS main score $r$-Pearson correlations with psychological variables $(n=85)$

\begin{tabular}{|c|c|c|c|c|}
\hline Variables & Leisure time & Protective behaviours & Professional life & Life limitations \\
\hline HADS-M ANXIETY & $0.493^{* \star}$ & $0.388^{* *}$ & $0.509^{* \star}$ & $0.521^{\star \star}$ \\
\hline HADS-M DEPRESSION & $0.385^{\star \star}$ & $0.330^{\star *}$ & $0.327^{\star *}$ & $0.430^{\star \star}$ \\
\hline HADS-M RAGE & $0.370^{\star \star}$ & $0.278^{\star *}$ & $0.351^{\star *}$ & $0.330^{\star *}$ \\
\hline SWLS & $-0.220^{*}$ & $-0.264^{*}$ & $-0.288^{\star \star}$ & $-0.294^{\star *}$ \\
\hline STAI STATE & $0.362^{\star *}$ & $0.245^{\star}$ & $0.356^{\star *}$ & $0.324^{\star *}$ \\
\hline STAI TRAIT & $0.322^{\star *}$ & 0.127 & $0.347^{\star \star}$ & $0.327^{\star \star}$ \\
\hline CATRIL LADDER TODAY & $-0.264^{*}$ & $-0.328^{\star \star}$ & $-0.287^{\star \star}$ & $-0.315^{\star \star}$ \\
\hline CANTRIL LADDER IN 4 WEEKS & $-0.408^{\star *}$ & $-0.381^{\star \star}$ & $-0.416^{\star \star}$ & $-0.469^{\star \star}$ \\
\hline GQL - Global health status & $-0.351^{\star \star}$ & $-0.258^{*}$ & $-0.249^{*}$ & $-0.265^{*}$ \\
\hline NV - Nausea and vomiting & 0.144 & 0.106 & 0.051 & 0.027 \\
\hline$P$ - Pain & 0.129 & 0.093 & $0.390^{\star *}$ & $0.354^{\star *}$ \\
\hline D - Dyspnoea & $0.300^{* *}$ & 0.102 & 0.117 & 0.153 \\
\hline S-Insomnia & 0.109 & $0.256^{*}$ & 0.202 & $0.224^{*}$ \\
\hline A - Appetite loss & 0.022 & 0.190 & -0.029 & 0.074 \\
\hline C-Constipation & 0.119 & 0.191 & 0.098 & 0.187 \\
\hline DIA - Diarrhoea & 0.127 & 0.110 & 0.008 & 0.145 \\
\hline FIN - Financial difficulties & 0.145 & 0.122 & 0.053 & 0.128 \\
\hline PF1 - Physical functioning & $-0.329^{\star \star}$ & $-0.297^{\star \star}$ & $-0.435^{\star \star}$ & $-0.400^{\star \star}$ \\
\hline RF1 - Role functioning & $-0.250^{*}$ & -0.106 & $-0.340^{\star *}$ & $-0.317^{\star \star}$ \\
\hline CF1 - Cognitive functioning & $-0.332^{\star *}$ & -0.173 & $-0.370^{\star *}$ & $-0.375^{\star *}$ \\
\hline EF1 - Emotional functioning & $-0.451^{\star \star}$ & $-0.284^{\star *}$ & $-0.551^{\star \star}$ & $-0.480^{\star \star}$ \\
\hline SF1 - Social functioning & $-0.483^{\star \star}$ & $-0.351^{\star \star}$ & $-0.517^{\star *}$ & $-0.488^{\star \star}$ \\
\hline
\end{tabular}

${ }^{*} p<0.05,{ }^{* *} p<0.01$.

The reduction of questions, in order to obtain the final version of the tool, was conducted in two stages. Firstly, the factors compose $d$ of fewer than 3 questions were removed [30]. Also, items with factor loadings lower than 0.4 were excluded. Moreover, the questions within the factors were subject to qualitative content analysis, to eliminate any inconsistencies.

Then, the final EFA was performed on 24 questions. The results of KMO sampling adequacy measure and Bartlett's sphericity test for 4-factor solution were adequate. They are presented in Table 3. The analysis revealed that MQLS includes 4 inherently coherent subscales (Supplementary Table S5). comprising 24 questions (Supplementary Table S4). The total variance explained by a 4 -factor scale is $66.92 \%$.

Each statement is scored from 1 (does not impair functioning) to 5 (precludes normal functioning). Raw scores are summed and then divided by the number of items on each subscale. The higher the score in a given subscale, the more difficulties the patient experiences in that area. In addition, the questionnaire enables reporting of the global QOL indicator in patients with mastocytosis, expressed as the mean score of all the items. The table below presents the final question arrangement (Table 4).

The reliability of individual subscales is presented in the table above (Table 4). All the Cronbach's $\alpha$ values were very high [30], ranging from $\alpha=0.812$ to $\alpha=0.918$.

The possible questionnaire scores (total) are between 24 and 120 points. The scores obtained by the patients are presented in Attachment 6.

The scores demonstrate a good correlation with the results of HADS, Cantril Ladder, STAI, and SWLS (Table 5), which confirms the high external construct validity of the questionnaire [30]. The mastocytosis type (systemic and cutaneous mastocytosis) did not differentiate the scores of the scale, therefore one can state that the scale is well suited for both groups (Supplementary Table S6).

\section{Discussion}

The QLMS questionnaire comprising 24 questions in four inherently coherent subscales (leisure time, protective behaviours, professional life, and life limitations) demonstrates high reliability and theoretical accuracy. 
QLMS (Quality of Life in Mastocytosis Scale) seems to be a reliable and theoretically accurate tool for measuring the quality of life, and it takes into account the specific difficulties experienced by patients with mastocytosis. Apart from the measurement of the global quality of life, QLMS offers a deeper assessment of the quality of a patient's life, including the difficulties in professional life, everyday life, leisure time, or those associated with protective behaviours. This scale is very promising as it may allow to diagnose which of these areas is the most challenging for the patient. This information will be valuable for the physicians and psychologists working with the patient, also because it points to the fields in which the patient requires special education. For instance, patients can have a limited understanding of the preventive strategies that could protect them against exacerbation of the disease symptoms (e.g. methods of avoiding insect bites).

Researchers across the world acknowledge the importance of QOL measurement and determination of the areas that are particularly problematic for patients. Our work on the Polish quality of life measure adjusted to the needs of mastocytosis patients started in 2015. While our study was ongoing, similar studies from other countries have been published. In 2018, The Mastocytosis Society, Inc. published a report presenting results of their survey [25]. Additionally, questionnaires focused on the quality of life in mastocytosis patients have been developed in the Netherlands (2016) [2] and Germany (2016) [31, 32].

The Mastocytosis Society, Inc. (TMS) is a non-profit organization established in 1995. Its goal is to support patients with mastocytosis, their families and caregivers. Through research and education, the organization offers assistance also to physicians. In 2010, TMS designed and implemented a survey (TMS Patient Survey) for patients of all ages with cutaneous or systemic mastocytosis, or with mast cell activation syndrome (MCAS) - and their caregivers - living in the United States. The survey explored various areas of life, concentrating on the issues associated with patients' life and functioning. In 2018, The Mastocytosis Society published a report regarding diagnosis, clinical and laboratory tests reported, comorbidities, dietary practices, possible familial occurrence of mast cell disorders, and perceptions concerning mast cell disorder-related medical care needs in the United States [25]. Even though both the QLMS and the American survey may be useful in the process of diagnosis and support medical professionals, assess the functioning level as well as problematic areas in life, are designed for people at least 18 years old and may be used in patients who have both types of mastocytosis, there are substantial differences between those two measures. Firstly, the Polish QLMS is a self-report method, whereas the American survey may be filled in by both the patient and her/his guardian/relative. Secondly, the Polish questionnaire is much shorter than the American survey. QLMS consists of 24 items divided to 4 subscales, whereas the American survey touches more areas such as ethnicity, disease symptoms classification, diagnostic process analysis, subjective assessment of the effectiveness of the medication, psychopathological symptoms (e.g. anxiety, depression), localization of the skin symptoms, localization of pain (e.g. bones, muscles, heart), as well as digestive system-related symptoms (e.g. diarrhoea, vomiting, stomach ache). Due to the fact that the Polish measure is shorter, the time for filling it in is consequently shorter too, therefore this test may produce less participant burden than the very long American survey.

In 2016, an article on the origin, development, and validation of the mastocytosis-specific quality of life questionnaire (MQLQ) was published in the Netherlands, complete with a short and convenient form of symptom assessment in mastocytosis (MSAF). The MQLQ is divided into 8 domains: "fatigue and mental health" which focuses on the burden of fatigue and concentration problems, "anaphylaxis" which measures the burden of anaphylactic reactions and the impact of carrying an epinephrine auto-injector, "skin symptoms" which documents the burden of pruritus and the aesthetic impact, "bone symptoms" which measures the impact of osteoporosis, "unfamiliarity" which consists of items focussed on the burden exacted by the ignorance of caretakers and the social environment concerning mastocytosis, "flushing" which measures the burden of flushing attacks, "general symptoms" which measures the impact of gastrointestinal symptoms, fear of a worsening prognosis and back pain, and the final domain "triggers" which documents the burden of triggers such as alcohol and temperature changes. The first section of the final MSAF consists of 14 items scoring pruritus, dizziness, headache, fatigue, flushing, mediator-release attacks, dyspnoea, rhinorrhoea, palpitations, nausea and vomiting, abdominal pain, bone pain, concentration problems, and depression. The second section of six items measures the impact of fatigue on daily functioning [2]. There are some differences and similarities between the Polish QLMS and the Dutch questionnaires. One of the basic differences between the Polish and Dutch questionnaires is the item's form. The QLMS items are statements referring to a specific situational context (e.g. have you installed an insect screen in windows or doors?), while the Dutch survey puts forward statements based on symptoms. One of the interesting differences is that the statements from Dutch questionnaires regarding the patient's cognitive functioning (e.g. remembering, concentration, clouding of consciousness). Furthermore, the Dutch questionnaire examines in detail the gastrointestinal symptoms (e.g. diarrhoea, abdominal pain) and skin symptoms (e.g. night pruritus). The similarities include the reference to the patient's environment (e.g. contact with insects, being active outside the home, and concerns about symptoms of the disease in contact with other people). Both ques- 
tionnaires draw attention to the subjectively perceived conditions, freedom of staying in specific rooms, and performing certain activities, as well as the feeling of anxiety related to the symptoms of the disease and social functioning (e.g. work and spending time with the loved ones). Interestingly, the Polish questionnaire pays great attention to the active spending of time by the patient, which is undoubtedly related to the quality of emotional life (e.g. holiday trips, holidays, walks). This shows how important social contact is despite the experienced physical and psychological symptoms (e.g. anxiety).

The German Mastocytosis Quality of Life Questionnaire (MC-QoL) is another questionnaire evaluating the quality of life in patients with mastocytosis. MC-QoL is a short and validated mastocytosis-specific questionnaire for the assessment of the quality of life. It comprises 27 questions and is intended for patients over 18 years of age, suffering from cutaneous or systemic mastocytosis. MC-QoL consists of four domains: symptoms, functioning/social life, emotions, and skin [31]. The Polish and German questionnaires share some similarities. First of all, they have a similar number of items (24 vs. 27, respectively). Also, in both questionnaires, the items refer to emotional states and social life (e.g. outdoor activities, contact with the close ones, problems faced while being away from home). There are main two differences between those questionnaires. Firstly, the German survey investigates the specific physical symptoms (e.g. itching, diarrhoea, and headache) while the Polish QLMS does not do that. Secondly, the German questionnaire consists of both questions and statements, accompanied by short definitions of symptoms, while the Polish QLMS consists of questions only.

The presented work was exploratory as there was no mastocytosis-specific quality of life questionnaire in Poland. Inspired by a literature review by Kohn-Wood and Hooper [32], the authors decided to create a measure that would be culturally tailored before moving towards adapting one of the existing questionnaires. Culturally tailored care, and also diagnosis, are proved to be effective in mental health service (Whaley, Davis [33]). The presented QLMS (Quality of Life in Mastocytosis Scale) is a Polish response to the need to measure the quality of life in patients with mastocytosis. It should be emphasized that the questionnaire concentrates on the psychological and psychosomatic factors, as well as on the way the patient perceives his or her functioning in various spheres. The questionnaire was based on subjective symptoms reported by patients. Its subscales, contrary to the Dutch questionnaire, do not focus on somatic symptoms such as anaphylaxis and osteoporosis. This is a single tool comprising 24 questions and covering the most important issues reported by patients. The possible questionnaire scores are between 0 and 120 points. The planned continuation of the study involves a comparison of the results according to the symptoms of mastocyto- sis, and validation of the tool in an independent group of patients with this disease. Including psychological and physical difficulties in the diagnostic and therapeutic process may be beneficial for the treatment and increase patients' quality of life.

\section{Acknowledgments}

This QLMS questionnaire is a result of collaboration between the patients of the Department of Allergology and the medical personnel - psychologists and physicians. The questionnaire could not be created without the engagement of patients with mastocytosis, their experience (the willingness to share their perception of mastocytosis), and the methods of coping with this rare disease.

Study conducted at: Department of Allergology, University Clinical Centre in Gdansk (Poland).

\section{Conflict of interest}

The authors declare no conflict of interest.

\section{References}

1. Niedoszytko M. Mastocytoza - rozrostowa choroba komórek tucznych związana z ryzykiem reakcji anafilaktycznej. [Mastocytosis - a hyperplastic mast cell disease associated with the risk of anaphylactic reaction]. Polski Merkuriusz Lekarski 2006; 126: 570-2.

2. van Anrooij B, Kluin-Nelemans J C, Safy M, et al. Patient-reported disease-specific quality-of-life and symptom severity in systemic mastocytosis. Allergy 2016; 71: 1585-93.

3. Bain BJ. Systemic mastocytosis and other mast cell neoplasms. Br J Haematol 1999; 106: 9-17.

4. Fearfield LA, Francis N, Henry K, et al. Bone marrow involvement in cutaneous mastocytosis. Br J Dermatol 2001; 144: 561-6.

5. Karnam US, Rogers A. Systemic mastocytosis. Dig Dis 1999; 17: 299-307.

6. Dereń-Wagemann I, Kuliszkiewicz-Janus M, Kuliczkowski K. Mastocytoza - rozpoznawanie i leczenie. [Diagnosis and treatment of mastocytosis]. Postepy Hig Med Dosw 2009; 63: 564-76.

7. Niedoszytko M, Jassem E, Kruszewski J. Mastocytoza - rozpoznanie i leczenie. [Diagnosis and treatment of mastocytosis]. Wydawnictwo Benkowski, Białystok 2007.

8. Niedoszytko M, Gruchała-Niedoszytko M. Mastocytoza - patogeneza, rozpoznanie, leczenie. [Pathogenesis, diagnosis and treatment of mastocytosis]. Alergia Astma Immunologia 2005; 10: 181-6.

9. Pardanani A, Akin C, Valent P. Pathogenesis, clinical features, and treatment advances in mastocytosis. Best Pract Res Clin Haematol 2006; 19: 595-615.

10. Jennings S, Russell N, Jennings B, et al. The mastocytosis society survey on mast cell disorders: patient experiences and perceptions. J Allergy Clin Immun Pract 2014; 2: 70-6.

11. Moura DS, Georgin-Lavialle S, Gaillard R, et al. Neuropsychological features of adult mastocytosis. Immunol Allergy Clin 2011; 34: 407-22. 
12. Moura DS, Sultan S, Georgin-Lavialle S, et al. Depression in patients with mastocytosis: prevalence, features and effects of mastinib therapy. PLoS One 2011; 6: e26375.

13. de Walden-Gałuszko K. Podstawy opieki paliatywnej. [Basic aspects of palliative care]. Wydawnictwo Lekarskie PZWL, Warsaw 2006.

14. de Walden-Gałuszko K, Majkowicz M. Jakość życia w chorobie nowotworowej. [Quality of life in neoplastic disease]. Wydawnictwo Uniwersytetu Gdańskiego, Gdańsk 1994.

15. Juczyński Z. Narzędzia pomiaru w promocji i psychologii zdrowia. Skala Satysfakcji z Życia. [Measurement tools in health promotion and psychology. The Satisfaction with Life Scale]. Pracownia Testów Psychologicznych Polskiego Towarzystwa Psychologicznego. Warsaw 2001; 134-8.

16. Wołowicka L, Jaracz K. Jakość życia w naukach medycznych. [Quality of life in medical sciences]. Wydawnictwo Uczelniane Akademii Medycznej w Poznaniu, Poznań 2001; 231-8.

17. Majkowicz M. Praktyczna ocena efektywności opieki paliatywnej - wybrane 133 techniki badawcze. [Practical assessment of the effectiveness of palliative care -133 selected research techniques] In: Ocena jakości opieki paliatywnej $w$ teorii i praktyce. [Assessment of the quality of palliative care in theory and in practice]. de Walden-Gałuszko K, Majkowicz M (eds.). Medical University, Gdańsk 2000; 21-42.

18. Zigmond AS, Snaith RP. The Hospital Anxiety and Depression Scale. Acta Psych Scand 1983; 67: 361-70.

19. Aaronson N, Ahmedzai S, Bergman B, et al. The European Organization for Research and Treatment of Cancer QLQC30: a quality-of-life instrument for use in international clinical trials in oncology. J Natl Cancer Inst 1993; 85: 365-76.

20. Spielberger CD, Gorsuch R, Lushene R, et al. Manual for the State-Trait Anxiety Inventory. Consulting Psychologists Press, Palo Alto 1983.

21. Sosnowski T, Wrześniewski K, Jaworowska A, et al. STAI - Inwentarz Stanu i Cechy Lęku. [STAI - State and Trait Anxiety Inventory]. Pracownia Testów Psychologicznych PTP. Warsaw 2011.

22. Mazur J, Woynarowska B, Kołoło H. Zdrowie subiektywne, styl życia i środowisko psychospołeczne młodzieży szkolnej w Polsce. Raport techniczny z badań HBSC 2006. [Subjective health, lifestyle and psychosocial environment of school-age children in Poland. A Technical report regarding 2006 HBSC studies]. IMiD. Warsaw 2007.

23. Jankowski KS. Is the shift in chronotype associated with an alteration in well-being? Biol Rhythm Res 2015; 46: 237-48.

24. Diener E, Emmons RA, Larsen RJ, et al. The Satisfaction with Life Scale. J Personality Assessment 1985; 49: 71-5.

25. Russel N, Jennings S, Jennings B, et al. The mastocytosis society survey on mast cell disorders: part 2-patient clinical experiences and beyond. J Allergy Clin Immunol Pract 2018; 7: 1157-65.

26. Oude Elberink J, de Monchy J, Golden D, et al. Development and validation of a health-related quality-of-life questionnaire in patients with yellow jacket allergy. J Allergy Clin Immunol 2002; 109: 162-70.

27. Oude Elberink J, de Monchy J, Van Der Heide S, et al. Venom immunotherapy improves health-related quality of life in patients allergic to yellow jacket venom. J Allergy Clin Immunol 2002; 110: 174-82.

28. Niedoszytko M, Majkowicz M, Chełmińska M, et al. Quality of life, anxiety, depression and satisfaction with life in patients treated with insect venom immunotherapy. Adv Dermatol Allergol 2012; 29: 74-9.
29. Worthington RL, Whittaker TA. Scale development research: a content analysis and recommendations for best practices. The Counseling Psychologist 2006; 34.

30. Hornowska E. Testy psychologiczne. Teoria i praktyka. [Psychological tests. Theory and practice]. Wydawnictwo SCHOLAR, Warsaw 2001.

31. Siebenhaar F, von Tschirnhaus E, Hartmann K, et al. Development and validation of the mastocytosis quality of life questionnaire: MC-QoL. Allergy 2016; 71: 869-77.

32. Kohn-Wood L, Hooper L. Cultural competency, culturally tailored care, and the primary care setting: possible solutions to reduce racial/ethnic disparities in mental health care. J Mental Health Counseling 2014; 36: 173-88.

33. Whaley AL, Davis KE. Cultural competence and evidencebased practice in mental health services: a complementary perspective. Am Psychol 2007; 62: 563-74. 